\title{
Morphological and Cytogenetic Effects of Isotox 25 Seed Treater ( $F$ ) (Lindane and Captan) on Roots and Chromosomes of Rye (Secale cereale L.)
}

\author{
John E. Dille, Elizabeth N. King and Marsha Bright \\ Department of Biology, Winthrop College, Rock Hill, South Carolina 29733. U.S.A.
}

Accepted March 1, 1985

The use of pesticides has increased enormously over the last 35 years. Worldwide, we now use about 2 billion kilograms per year of 40,000 different pesticides (Miller 1982). Many of these chemical compounds exhibit detrimental effects on organisms other than the pests they were designed to control. For example, 2,4-D, an herbicide used for weed control, causes chromosome aberrations and abnormal mitosis in cotton (Basler and Nakazawa 1961), onion (Ryland 1948) and horsebeans (Sawamura 1963). Ferbam, a fungicide used on fruits, nuts and tobacco, causes chromosomal damage on onion root tips (Prasad and Pramer 1968). Vitavax-200 and Dithane S-60 are also well known pesticides used to control pathogenic fungi affecting wheat. Both reduce the mitotic index and greatly increase the frequency of chromosomal bridge formation during anaphase in bread wheat (Nahla and Soliman 1980). Njagi and Gopalan (1981) showed that the insecticides summithion, lannate, Carbicron, Thiodan and Kelthane, the fungicides Diathane M-45 and Aldrin, and the herbicides Ramrod, Lasso, Round-up and Gammoxone all produce cytogenetic changes in Vicia faba. Hocking and Thomas (1979) reported that the fungicide Captan inhibited root formation in cuttings of ornamental plants. Lindane was shown to be phytotoxic to 3-day old garden pea seedlings (Charnetski et al. 1973).

The present study reports on the effects of a proprietary seed treatment product containing both an insecticide (Lindane) and a fungicide (Captan) on rye roots.

\section{Materials and methods}

Clean dry seeds of rye (Secale cereale L.) var. Snoopy were used throughout this study. The seeds were dusted at recommended rates for cereals with Ortho's Isotox 25 Seed Treater (F). The active ingredients include $25 \%$ Lindane (gamma isomer of benzene hexachloride, CAS No. 58-89-9) and $12.5 \%$ Captan (N- (trichloromethyl)thio-4-cyclohexene-1,2-dicarboximide, CAS No. 133-06-2). The treated and control seeds (100 each) were germinated at $20^{\circ} \mathrm{C}$ in darkness.

Ten root tips from treated and control were removed when 1-3 cm long and placed directly in ice water at $5^{\circ} \mathrm{C}$ for $24 \mathrm{~h}$ to accumulate somatic cells in metaphase (Nakata et al. 1977). The root tips were treated to saturated bromonaphthalene for $1 \mathrm{~h}$ at $20^{\circ} \mathrm{C}$, stained in $3 \%$ aceto-orcein for $23 \mathrm{~h}$ at $5^{\circ} \mathrm{C}$ and rinsed several times in running tap water. Chromosome spreads were made using the squash technique 
on subbed slides and an Ikonen micro-press (Winnipeg Man.) was used to further flatten and spread the chromosomes. They were made permanent with HistoFreeze (Fisher Cat. No. 12-645-30), air dried, soaked in xylene and mounted with Pro-Texx.

\section{Results and discussion}

The rye seeds treated with Isotox- 25 showed a slightly higher germination rate $(91.3 \%)$ than the controls $(86.3 \%)$. Six days after first emergence of the radicle, the average length of the untreated roots $(92.3 \mathrm{~mm})$ was much greater than the treated roots $(7.7 \mathrm{~mm})$. The ends of the treated roots were swollen and club-shaped just proximal to the root tip and measured about $1.6 \mathrm{~mm}$ in diameter. The diameter of the untreated root tips was near $0.3 \mathrm{~mm}$. The clubbing did not appear until 2 days after emergence of the radicle.

The diploid number of chromosomes for rye is 14 . Minor variations from this (for example, 12 or 13) in the ten control slides represent chromosome loss due to the cytological technique and not the normal condition in the living plant. The ten slides of treated root tips show cells exhibiting large and varying numbers of chromosomes ranging from 14 to 190 . For example, slide No. 6 showed cells with 28,85 , 49,96 and 67 chromosomes. Table 1 indicates chromosome numbers of 5 cells from one control slide $(0)$ and ten treated slides $(1-10)$. The modal ploidy is probably more useful than the mean ploidy level (Eggen 1970). Many of the cells contained chromosomes near the octoploid number of $8 n=56$.

Since the chromosome number of a cell doubles with each division without cytokinesis, one would expect multiples of $14(28,56,112,224)$ in the treated cells. Such is not the case as most of the cells contained numbers of chromosomes other than exact multiples of the diploid condition. Perhaps some cytokinesis occurs that prevents their recovery but it was not observed in this material due to pretreatment with cold and bromonaphthalene.

It is suggested that Lindane is the active ingredient responsible for the above observations. This is supported by the work of others (Epstein and Legator 1971,

Table 1. Chromosome counts of five cells from one control (0) and ten treated $(1-10)$ root tips

\begin{tabular}{ccccc}
\hline $\begin{array}{c}\text { Slide } \\
\text { no. }\end{array}$ & $\begin{array}{c}\text { Chromosome numbers } \\
\text { of five cells }\end{array}$ & $\begin{array}{c}\text { Modal } \\
\text { ploidy }\end{array}$ & Mean & $\begin{array}{c}\text { Mean } \\
\text { ploidy }\end{array}$ \\
\hline 0 & $14,14,14,12,14$ & $2 \mathrm{n}$ & 14 & $2 \mathrm{n}$ \\
1 & $55,37,28,53,76$ & $8 \mathrm{n}$ & 50 & $8 \mathrm{n}$ \\
2 & $38,51,49,55,32$ & $8 \mathrm{n}$ & 45 & $7 \mathrm{n}$ \\
3 & $53,29,54,61,50$ & $8 \mathrm{n}$ & 49 & $7 \mathrm{n}$ \\
4 & $74,27,51,55,83$ & $8 \mathrm{n}$ & 58 & $9 \mathrm{n}$ \\
5 & $38,54,61,14,40$ & $8 \mathrm{n}$ & 41 & $6 \mathrm{n}$ \\
6 & $28,85,49,96,67$ & $14 \mathrm{n}$ & 65 & $10 \mathrm{n}$ \\
7 & $53,50,28,51,51$ & $8 \mathrm{n}$ & 46 & $7 \mathrm{n}$ \\
8 & $48,54,71,163,53$ & $8 \mathrm{n}$ & 78 & $12 \mathrm{n}$ \\
9 & $62,52,31,87,49$ & $9 \mathrm{n}$ & 56 & $8 \mathrm{n}$ \\
10 & $27,28,56,190,37$ & $4 \mathrm{n}$ & 68 & $10 \mathrm{n}$ \\
\hline
\end{tabular}


Vintila et al. 1979) who have shown that Lindane causes many types of chromosomal aberrations in a wide variety of plant and animal species. The thickening or "clubbing" of the roots treated with Lindane was noted in peas by Charnetski et al. (1973), in wheat and broad bean by Lazar-Keul et al. (1979), in corn, wheat, sunflowers and cabbage by Kostoff (1949) and in onion and strawberries by Scholes (1953). Apparently Lindane acts to prevent normal microtubular formation (Jeanne 1978) and cell wall development (Charnetski et al. 1973). This leads to abnormal mitosis (resembling $\mathrm{C}$-mitosis) which produces large heteroploid cells and results in short swollen root tips. Recovery from such treatment was not investigated in the present work.

Lindane combined with Captan and used as a seed treater to control insects and fungi on the seeds of many plants has been shown, in the present work on rye roots, to decrease cell elongation, increase cell size and root diameter and produce high levels of polyploidy.

\section{Summary}

Isotox 25 Seed Treater (F) was applied at recommended rates to dry seeds of rye which were allowed to germinate. Roots from treated seeds were short and thickened near the apex. Cells of root tips showed greatly enlarged cells possessing nuclei exhibiting various levels of polyploidy.

\section{References}

Basler, E., and Nakazawa, K. 1961. Effects of 2,4-D on nucleic acids of cotton cotyledon tissue. Bot. Gaz. 122: 228-232.

Charnetski, W. A., Lichtenstein, E. P. and Evert, R. F. 1973. Effects of lindane on cell structure of pea roots. Can. J. Bot. 51: 2111-2117.

Eggen, R. R. 1970. Cytogenetics. American Society of Clinical Pathologists. Chicago, IL. pp 215.

Epstein, Samuel, S. and Legator, Marvin S. 1971. The Mutagenicity of Pesticides, Concepts and Evaluation. The MIT Press, Cambridge, p. 181-182.

Hocking, P. J. and Thomas, M. B. 1979. Effect of IBA in combination with Thiram, Captan and Benomyl on the rooting of 4 ornamental species. N. Z. J. Exp. Agric. 7(3): 263-270.

Jeanne, N. 1978. Effets du Lindane sur la division, le cycle cellulaire et les biosynthèses de deux algues unicellulares. Can. J. Bot. 57: 1464-1472.

Kostoff, Dontcho 1949. Induction of cytogenetic changes and atypical growth by Hexachlorocyclohexane. Science 109: 467-468.

Lazar-Keul, G., Soran, V., Vintila, R., Polizu, A. and Keul, M. 1979. Effect of Lindane and Methychlor on cell nucleus DNA content of wheat (Triticum vulgare) and broad bean (Vicia faba) root meristems. Rev. Roum. Biol. 24: 69-75.

Miller, G. Tyler 1982. Living in the Environment. Wadsworth Publishing Company Inc., Belmont, CA, p. E83.

Nahla, R. Al-Najjar and Soliman, Atef S. 1980. Cytological effects of fungicides I. Mitotic effects of Vitavax-200 and Dithane S-60 on wheat and two related species. Cytologia 45: 163-168.

Njagi, G. D. E. and Gopalan, H. N. B. 1981. Mutagenicity testing of herbicides, fungicides and insecticides I. Chromosome aberrations in Vicia faba. Cytologia 46: 169-172.

Nakata, N., Yasumuro, Y. and Sasaki, M. 1977. An acetocarmine-giemsa staining of rye chromosomes. Jap. J. Gent. 52: 315-318. 
Prasad, I. and Pramer, D. 1968. Genetic effects of Ferbam on Asperigillus niger and Allium cepa. Phytopathology 58: 1188-1189.

Ryland, A. G. 1948. A cytological study of the effects of colchicine, indole-3-acetic acid, potassium cyanide and 2,4-D on plant cells. J. Elisha Mitchell Sci. Soc. 64: 117-125.

Sawamura, S. 1964. Cytological studies on the effect of herbicides on plant cells in vivo I. Homonic herbicides. Cytologia 29: 86-102.

Scholes, Mary, E. 1953. The effect of hexachlorocyclohexane on mitosis in roots of the onion (Allium cepa) and strawberry (Fragaria vesca). J. Hort. Sci. 28: 49-67.

Vintila, Rozalia, Lazar-Keul, G., Keul, M. and Soran, V. 1979. Phytotoxische Thirahexalinwirkungen auf Weizenpflanzen. Rev. Roum. Bio. 24: 133-141. 